\title{
CARTEIRA DE ALTERIDADE: TRANSFORMAÇÕES MAMAINDÊ (NAMBIQUARA) *
}

Joana Miller

Alguns meses depois de iniciar o meu trabalho de campo com os Mamaindê, um grupo Nambiquara situado no noroeste do estado de Mato Grosso, um jovem de cerca de 30 anos falou-me sobre a importância dos seus enfeites corporais, dizendo-me que eles eram como a carteira de identidade dos brancos. ${ }^{1}$ Em seguida, ele justificou esta comparação explicando-me que, quando os brancos perdem a sua carteira de identidade, a polícia os leva presos, argumentando que sem este objeto eles não são ninguém. O mesmo se passa, ele acrescentou, quando os espíritos da floresta roubam os enfeites dos Mamandê: eles os escondem dentro de buracos na floresta e, deste modo, o espírito (yauptidu) da pessoa fica preso. Ela adoece, não reconhece mais os seus parentes. "Sem os seus enfeites ela não é ninguém", ele concluiu.

Pretendo explorar aqui a comparação feita pelo jovem mamaindê entre os seus enfeites corporais e a carteira de identidade. A importância atribuída a tais objetos, neste caso, remete aos perigos relacionados à possibilidade de perdê-los em situações específicas. Quando se trata dos enfeites corporais, enfatizam-se os riscos e as consequências de tê-los roubados pelos espíritos da floresta. Quando se trata da carteira de identidade, enfatiza-se o perigo envolvido nas relações estabelecidas com a polícia. A comparação feita pelo jovem mamaindê não foi, portanto, apenas entre os seus enfeites corporais e a carteira de identidade, mas também entre os espíritos da floresta e a polícia.

Meu objetivo é refletir sobre estas duas comparações contidas na explicação do meu informante e investigar como este tipo de formulação pode nos dizer algo sobre a relação que os Mamaindê estabelecem entre os objetos e aqueles que os portam, de modo que seja possível afirmar que, em certos contextos relacionais, uma pessoa desprovida de determinados objetos "não é ninguém". 


\section{Enfeites, roupas e documentos}

Comparações como a que foi feita pelo jovem mamaindê são frequentemente reportadas pelos antropólogos. Conklin (1997:715) relata o caso de um líder kayapó que, ao ser impedido de entrar em um tribunal brasileiro por usar pinturas corporais e adereços de penas coloridas, respondeu ao juiz, que exigia que ele se apresentasse de terno e gravata, que os seus adornos tradicionais eram o terno e a gravata dos índios. Se o meu informante mamaindê comparou os seus enfeites corporais à carteira de identidade dos brancos, no caso relatado por Conklin, os enfeites usados pelos Kayapó foram comparados às roupas dos brancos.

Conklin cita este evento como uma ilustração da habilidade com que alguns povos indígenas passaram a utilizar os símbolos e as imagens corporais como ferramentas políticas, especialmente no novo contexto das relações interétnicas que se configurou a partir dos anos 1980. A centralidade das imagens corporais para a expressão da identidade étnica seria, segundo esta autora, o resultado da imposição aos índios de noções exógenas de identidade e de autenticidade cultural segundo as quais os adornos corporais são tomados como símbolos que representam a identidade daqueles que os portam. Ela argumenta, neste sentido, que:

Os símbolos visuais estão no centro desta história porque a política da aliança indígena-ambientalistas é, antes de mais nada, uma política simbólica [...] Símbolos são importantes em todas as políticas, mas eles são centrais no ativismo político amazônico. Na falta de cacife eleitoral ou de influência econômica, o "capital simbólico" (Bourdieu 1977) da identidade cultural é um dos únicos recursos políticos dos índios brasileiros (Conklin 1997:713).

De acordo com esta perspectiva, as comparações feitas pelo jovem mamaindê e pelo líder kayapó referidas acima sugerem que, ao menos no contexto da interação com os brancos, os enfeites corporais seriam concebidos pelos índios como símbolos identitários do mesmo modo que o são as roupas e a carteira de identidade para a audiência ocidental. ${ }^{2}$ Neste caso, a relação estabelecida entre os enfeites e aqueles que os portam é predicada nos termos da ontologia ocidental. Mas o que acontece se examinarmos este tipo de comparação tomando como referência as concepções indígenas dos enfeites corporais? Levando em conta que o corpo e os processos ligados à sua fabricação (o que inclui ornamentação, perfuração, tatuagem, pintura) são centrais para o entendimento dos sistemas sociocosmológicos ameríndios (Seeger, Da Matta \& Viveiros de Castro 1979), é interessante notar que, nos 
dois casos mencionados acima, as roupas e a carteira de identidade tenham sido comparadas pelos índios justamente aos seus enfeites corporais.

Em um artigo sobre a relação entre xamanismo e contato interétnico na Amazônia indígena, Vilaça (1999:246) analisa o significado das roupas ocidentais nos processos de mudança de identidade e argumenta que, se tomarmos como referência as concepções indígenas do corpo, não há nenhuma diferença substantiva entre as roupas ocidentais e os ornamentos ou vestes animais usados pelos xamãs. Ambos constituem formas de diferenciação e de transformação do corpo idênticas àquelas que decorrem de práticas alimentares e da troca de substância pela proximidade física frequentemente descritas nesta região. Neste sentido, não é preciso supor que, ao se apropriarem das roupas ocidentais, os povos indígenas necessariamente deveriam se apropriar de novas noções de identidade e cultura. Penso que, embora a carteira de identidade tenha sido comparada pelos Mamaindê aos seus enfeites corporais, estes objetos estão longe de serem concebidos como símbolos identitários.

A partir da descrição etnográfica dos Mamaindê, pretendo demonstrar que a comparação feita pelo meu informante indica que a carteira de identidade é vista como um enfeite corporal, tal como os Mamaindê o concebem, e não o contrário. Deste modo, argumento que para este grupo Nambiquara a carteira de identidade remete, sobretudo, às noções de alteridade e de transformação, mais do que às ideias de identidade ou de representação. Sugiro que, assim como os ornamentos corporais, a carteira de identidade é um índice das relações que constituem a pessoa neste contexto etnográfico, mais do que um símbolo que a representa. A questão que se coloca aqui é, portanto, como entender a comparação feita pelo jovem mamaindê para explicar a importância de seus ornamentos corporais quando os objetos não representam a pessoa mas a constituem.

Vejamos então como, para os Mamaindê, os enfeites corporais podem ser considerados partes constitutivas da pessoa e em que medida eles estão associados à capacidade de transformação.

\section{Os enfeites corporais como componentes da pessoa}

Os Mamaindê dizem que, além dos enfeites visíveis, possuem também enfeites internos que só o xamã é capaz de enxergar e de tornar visíveis durante as sessões de cura. O que torna um enfeite visível ou invisível não é uma característica intrínseca a ele, mas a capacidade visual do observador. Do ponto de vista do xamã, um ser capaz de adotar múltiplos pontos de vis- 
ta, o corpo dos Mamaindê revela-se sempre como um corpo enfeitado com muitas voltas de colar de contas pretas feitas do coco de tucum, mesmo que, aos olhos dos não xamãs, a pessoa não esteja usando nenhum enfeite. ${ }^{3}$ Tudo se passa como se, para o xamã, não existisse a possibilidade de se ter um corpo completamente nu; o corpo humano, em sua integralidade, apresenta-se sempre como um corpo devidamente ornamentado.

Outros tipos de seres também possuem seus próprios enfeites corporais. No sonho, locus privilegiado de atuação xamânica, vários animais costumam se revelar em sua forma humana e são descritos como pessoas (nagayandu) enfeitadas. Embora não haja um consenso na descrição desses enfeites, os Mamaindê enfatizam que eles são feitos de outro material, diferindo, assim, dos enfeites usados por eles próprios. Os colares do "dono" dos porcos vistos no sonho, por exemplo, são feitos de sementes de urucum e não de contas de tucum como as usadas pelos Mamaindê. O espírito "dono" do macaco-aranha possui apenas um colar que não é feito com fio de algodão, como o dos Mamaindê, mas com um fio de teia de aranha. Neste sentido, o tipo de enfeite que se tem indica o tipo de gente que se é a partir do amplo espectro de humanidade característico das cosmologias ameríndias.

Os estudos sobre a ornamentação corporal na Amazônia indígena costumam enfatizar que os enfeites são aparatos de humanização que podem ser usados ora para marcar diferenças internas a um grupo social (Turner 1992; Vidal 1992; Erikson 1996), ora como sinais diacríticos que marcam diferenças entre grupos sociais distintos (Agostinho 1974; Hugh-Jones 1979, 2002). Em trabalhos anteriores (Miller 2005, 2009), argumentei que, para os Mamaindê, os enfeites corporais marcam sobretudo diferenças existentes entre as várias espécies de sujeitos, o que inclui também os animais e os espíritos. Neste caso, toma-se como referência uma noção de humanidade ampliada que abrange outros tipos de seres com os quais se estabelecem relações sociais. Assim, se para alguns grupos ameríndios os enfeites corporais foram relacionados a mecanismos classificatórios que marcam distinções sociológicas, para os Mamaindê, os enfeites parecem remeter a um processo de especiação ou de distinção ontológica. ${ }^{4}$

O ato de enfeitar é concebido como um ato de cuidado e de afeto e está diretamente relacionado ao parentesco. Os Mamaindê descrevem o ato de enfeitar as crianças pequenas, destinatários privilegiados dos colares de contas pretas feitos por seus parentes (principalmente mães e avós), como um ato de carinho e proteção. ${ }^{5}$ Quando enfeitam seus filhos pequenos, as mulheres dizem que estão cuidando deles e protegendo-os do ataque de espíritos malévolos. A ideia de carinho e cuidado também está presente 
quando as mulheres enfeitam seus maridos. Conforme me explicaram, é o fato de enfeitar e alimentar os seus maridos que faz com que as mulheres possam se referir a eles como "minha criação" (da mãindu), mesmo termo usado para se referir aos seus animais de estimação e também aos seus filhos. Por outro lado, diz-se que as crianças que não usam nenhuma volta de colar em seu corpo são crianças "sem parentes, abandonadas". Portanto, o ato de enfeitar conecta a pessoa a um grupo de parentes que compartilham os mesmos tipos de enfeites corporais. Os enfeites são, neste caso, índices das relações que conectam a pessoa aos seus parentes e, de certa forma, o material mesmo do qual essas relações são feitas. ${ }^{6}$

A ideia de que o corpo enfeitado seria a imagem da humanidade, da sociabilidade, do parentesco, por oposição ao corpo nu, antítese da vida em sociedade, também é expressa pelos Matis, grupo de língua pano da Amazônia ocidental. Segundo Erikson (1996:233), os enfeites corporais usados pelos Matis ao mesmo tempo pontuam e produzem o desenvolvimento fisiológico do indivíduo e são signos de humanidade e de sociabilidade. À medida que a pessoa vai crescendo e ampliando as relações de parentesco que a conectam ao grupo, ela vai recebendo mais enfeites corporais. Os espíritos Maru, antissociais, solitários e grotescos, são descritos como seres sem enfeites corporais, enquanto os espíritos dos ancestrais (Marawin) são belos e hiperenfeitados. Neste caso, os enfeites não são apenas a imagem da sociabilidade, mas também componentes do corpo, na medida em que produzem o seu desenvolvimento fisiológico.

Seeger (1980) observa algo semelhante para os Suya. Para este grupo, a ornamentação de determinadas partes do corpo serve para aumentar e produzir capacidades socialmente valorizadas - neste caso, a fala e a audição que, assim, são concebidas como atributos corporais. As partes do corpo que não são enfeitadas, como os olhos, por exemplo, estariam associadas à feitiçaria e a outras forças a-sociais relacionadas à visão. Noto que, em ambos os casos, os enfeites são a imagem da sociabilidade que é pensada como um atributo corporal.

Mas, no caso dos Mamaindê, se os enfeites corporais são imagens da vida em sociedade, ligando a pessoa a um grupo de parentes que usam os mesmos tipos de enfeites e com os quais ela constitui um tipo de corpo coletivo que compartilha comida e enfeites, eles são também aquilo que a conecta a um universo mais amplo de subjetividades. A ênfase na necessidade de se enfeitarem as crianças pequenas se deve justamente à maior possibilidade de elas serem capturadas por espíritos malévolos e adoecerem.

Grande parte das doenças que afetam os Mamaindê é descrita como uma perda ou troca de enfeites corporais com outros tipos de seres. Neste 
contexto, os enfeites são associados à noção de espírito. Diz-se de uma pessoa doente que ela perdeu os seus enfeites (wasain'du), ou o seu espírito (yauptidu). Neste caso, o termo wasain'du (coisa), usado para designar todos os pertences de uma pessoa e especialmente seus enfeites corporais, costuma ser traduzido como "espírito" em português, indicando que a perda dos enfeites corporais equivale à perda do próprio espírito.

O que eu quero mostrar aqui é que se, por um lado, os enfeites são concebidos como componentes do corpo, ou dito de outro modo, são índices das relações de parentesco, carinho e afeto que ligam a pessoa a um grupo de parentes com corpos semelhantes, por outro lado, eles são também aquilo que confere ao corpo sua capacidade de transformação, ou sua instabilidade, para usar o termo escolhido por Vilaça (2005) para caracterizar as concepções ameríndias do corpo, pois são eles também que conectam a pessoa a outros tipos de seres. Neste contexto, os enfeites estão relacionados à noção de espírito e à capacidade de transformação.

A troca de enfeites com outros tipos de seres costuma ser descrita pelos Mamaindê como um processo de desaparentamento que equivale a uma troca de perspectivas. O espírito "dono" do macaco-aranha, por exemplo, costuma roubar os colares dos Mamaindê, colocando o dele em seu lugar. A pessoa afetada fica muito doente, seu espírito passa a viver no mato, acompanhando aquele que se apoderou dos seus enfeites. Quando isso acontece, diz-se que o espírito do doente casou-se com o espírito "dono" do macaco-aranha. O doente passa então a ver os seus próprios parentes como se fossem "bichos". Sem os seus enfeites, a pessoa "não é ninguém", como afirmou o jovem mamaindê citado no início, justamente porque passa a ser alguém para outros tipos de seres, deixando de reconhecer os seus próprios parentes.

Durante as sessões de cura, o xamã procura recuperar os enfeites roubados do doente e retira os colares deixados em seu corpo pelo espírito agressor, substituindo-os por novos colares. Só então o doente volta a reconhecer os seus próprios parentes e começa a melhorar. A cura xamânica pode ser descrita, neste sentido, como um processo de (re)produção de pessoas humanas específicas. Ao colocar novamente os enfeites perdidos no corpo do doente, o xamã o reconecta aos seus parentes desfazendo as relações que o ligavam a outros tipos de seres e interrompendo, assim, o processo de transformação. ${ }^{7}$

Os enfeites corporais dos Mamaindê estão, portanto, intimamente relacionados à constituição da pessoa e à sua capacidade de transformação, indicando, sobretudo, a instabilidade da condição humana neste contexto etnográfico. 


\section{Os enfeites corporais como objetos xamânicos}

É preciso dizer ainda que os colares que o xamã coloca no corpo dos doentes durante as sessões de cura são dados a ele pelos espíritos dos mortos. O poder xamânico é descrito como a posse de muitos enfeites corporais que o xamã recebe dos espíritos dos mortos e também do xamã que o iniciou nas técnicas do xamanismo. Por isso, além das crianças pequenas, que como eu disse são os principais destinatários dos colares feitos pelos seus parentes, o xamã também está sempre usando muitas voltas de colar, diferenciando-se, assim, das outras pessoas. De posse dos enfeites dos mortos, o xamã passa a ver o mundo como eles e se torna capaz de enxergar os enfeites que para as pessoas comuns são invisíveis. Tudo se passa como se, do ponto de vista do xamã, o corpo fosse translúcido, não encobrindo os enfeites que, para as pessoas comuns, são invisíveis. ${ }^{8}$

O conhecimento xamânico consiste, portanto, em saber como os espíritos veem os Mamaindê e se veem a si mesmos. Os enfeites, que para os não xamãs são internos ao corpo e invisíveis, são justamente a parte do corpo que os torna visíveis aos espíritos. É precisamente por compartilhar a perspectiva dos espíritos que o xamã só enxerga corpos enfeitados.

Ao tornar visíveis os enfeites internos dos doentes durante as sessões de cura, o xamã mostra aos Mamaindê as relações que os constituem como pessoas humanas singulares, revelando quem eles realmente são, quem são os seus verdadeiros parentes. É preciso, para isso, recorrer à perspectiva dos mortos, pois só assim os Mamaindê podem se definir novamente como pessoas humanas. ${ }^{9}$

Taylor e Viveiros de Castro (2006) observaram que nas cosmologias ditas animistas ou perspectivistas, nas quais a humanidade engloba outras espécies capazes de ocupar a posição de sujeito, as pinturas corporais não são um apanágio exclusivo da espécie humana, constituindo o condensado visual de uma cultura própria a cada espécie. Assim, o que pode parecer aos humanos como o pelo pintado do jaguar, por exemplo, é visto pelos congêneres do jaguar como desenhos ou motivos pintados sobre o corpo humano. Se o pelo pintado do jaguar é a pele do jaguar vista do ponto de vista de sua presa, para os seus congêneres, no entanto, essas manchas são vistas como pinturas corporais ou, como dizem Taylor e Viveiros de Castro: "são sua roupa de sujeito-jaguar vista do interior, tal como ela é percebida pelos membros de seu próprio coletivo". Deste modo, "conhecer as pinturas corporais próprias de outros coletivos é conhecer a aparência específica que os Outros oferecem aos seus parentes, é conhecer em suma a sua 'face oculta'" (Taylor \& Viveiros de Castro 2006:169). Este tipo de saber, eles acrescentam, forma um componente essencial da "ciência indígena". 
O conhecimento xamânico, tal como ele é concebido pelos Mamaindê, parece ser um caso exemplar do que nos dizem Taylor e Viveiros de Castro, já que implica, justamente, tornar visíveis os enfeites que normalmente são invisíveis e internos ao corpo ou, nas palavras destes autores, tornar visível "o corpo visto do interior". Devo acrescentar que isto indica necessariamente um processo de transformação: de posse dos enfeites dos mortos, o xamã passa a chamá-los de "meus parentes" (da waintadu - literalmente "meus muitos") e é reconhecido por eles como um semelhante, tornando-se capaz de ver os Mamaindê como os mortos os veem. Transformado em um morto entre os vivos, o xamã é o único capaz de interromper o processo de transformação desencadeado pela doença, que consiste precisamente na captura dos enfeites corporais dos doentes pelos espíritos do mato. Para isso, ele deve tornar visíveis os enfeites internos dos doentes, colocando em seus corpos novos enfeites, revelando assim quem são os seus verdadeiros parentes.

Os enfeites do xamã não são, portanto, representações ou símbolos do seu poder, mas índices das relações que ele estabelece com outros tipos de seres, tornando-o um ser múltiplo e diferente de si mesmo. Penso que é por isso que os Mamaindê descrevem o poder xamânico como a posse de muitos enfeites corporais. Mais do que o condensado visual de uma cultura própria a cada espécie, como observaram Taylor e Viveiros de Castro, os enfeites do xamã mamaindê são também a expressão material de sua capacidade de adotar outros pontos de vista. Talvez tenha sido por isso que um xamã me explicou certa vez que os espíritos do mato roubavam os enfeites corporais dos Mamaindê para ter xamãs para eles.

Os Mamaindê dizem ainda que os enfeites do xamã são feitos pelos mortos; são eles os verdadeiros agentes. Assim, costuma-se dizer que um xamã nunca está só, ele está sempre acompanhado por uma legião de espíritos, invisíveis aos olhos dos não xamãs, que têm sua expressão material nos enfeites usados por ele. O xamã é, neste sentido, uma pessoa composta por um excesso de enfeites que indicam um excesso de relações: ele é parente dos vivos, mas também dos mortos. Costuma-se dizer que o xamã se casa com uma mulher-espírito, também descrita como uma onça, que passa a acompanhá-lo onde quer que ele vá. Deste modo, o xamã geralmente é definido como alguém que tem duas mulheres, o que, a meu ver, é uma forma de defini-lo como um ser composto por relações que ultrapassam o universo social dos vivos. Como vimos, a construção do parentesco entre os vivos depende da relação de parentesco que o xamã estabelece com os $\operatorname{mortos}^{10}$. Já o estado de solidão, desamparo e ausência de relações de parentesco é descrito pelos Mamaindê como uma ausên- 
cia de enfeites corporais: "uma criança sem enfeites é uma criança sem parentes, abandonada", dizem. ${ }^{11}$

Em um artigo seminal sobre o perspectivismo ameríndio, Viveiros de Castro (2002 [1996]:361) comenta o estatuto ontológico dos objetos nas cosmologias ameríndias e observa que "os artefatos possuem esta ontologia interessantemente ambígua; são objetos, mas apontam necessariamente para um sujeito, pois são como ações congeladas, encarnações materiais de uma intencionalidade não material". Neste sentido, é possível dizer que os enfeites corporais do xamã mamaindê são índices de agências estrangeiras que compõem o seu corpo.

O corpo superenfeitado do xamã mamaindê é, assim, uma boa imagem da capacidade de transformação constitutiva dos xamãs na Amazônia que, posteriormente, Viveiros de Castro (2006) sugeriu pensar como um estado de autodiferença que aproximaria as noções de xamã e de espírito nesta região. Segundo este autor, essas noções não se referem a uma categoria taxonômica, mas indicam um momento de indiscernibilidade entre o humano e o não humano semelhante àquele descrito pelos mitos, apontando para um estado de autodiferença que torna espíritos e xamãs seres diferentes de si mesmos, com uma capacidade infinita de transformação.

Viveiros de Castro (2006:321) observa, neste sentido, que é comum na Amazônia uma reverberação entre as posições de xamãs e de espíritos, de modo que os xamãs podem ser chamados de "espíritos" e os espíritos podem ser ditos "xamãs". É interessante notar que para os Mamaindê o xamã pode ser referido como "aquele que tem espírito" (waninsogidu), ${ }^{12}$ mas no contexto da atuação xamânica costuma-se traduzir o termo wasaindu (coisa) por "espírito", em português. Quando um xamã deixa de observar as restrições alimentares e sexuais que envolvem seu ofício, por exemplo, diz-se que ele perdeu as suas "coisas", referindo-se aos seus enfeites corporais, ou que o seu espírito foi embora. O mesmo pode ser dito de uma pessoa doente.

Mas se o conhecimento xamânico é descrito como a posse de muitos enfeites corporais, o xamã não é o único a possuí-los. Ao contrário, como eu disse acima, do seu ponto de vista, o corpo dos Mamaindê se revela sempre como um corpo enfeitado. O xamã se diferencia das outras pessoas por ter mais enfeites e por tomar uma série de precauções para mantê-los consigo. De certa forma, todos aqueles que estiveram doentes e tiveram seus enfeites recuperados pelo xamã podem ser considerados um pouco xamãs.

Devo ressaltar que os enfeites corporais, sejam eles internos ou externos, não são de modo algum um atributo ontológico fixo de cada espécie de sujeito. Não parece fazer muito sentido para os Mamaindê definir um 
tipo de enfeite específico usado por cada espécie de sujeito. O que os Mamaindê enfatizam é justamente a impossibilidade de saber algo sobre os enfeites de alguém sem que esta pessoa esteja inserida em uma relação. Quando eu lhes perguntava, por exemplo, se eles já nasciam com enfeites internos ao corpo, as respostas variavam muito. No entanto, o que todos enfatizavam era o fato de que, nos casos de doença - quando se tem os enfeites roubados/trocados por outros tipos de sujeitos - o xamã deve tornar os enfeites internos dos doentes visíveis e trazer novos enfeites para colocar em seus corpos.

O que parece paradoxal neste caso é que os enfeites são aquilo que define os Mamaindê como pessoas humanas singulares e, ao mesmo tempo, o que os torna "diferentes de si mesmos"; são feitos pelos mortos e, de certo modo, materializam seu ponto de vista. Nos momentos de doença, é preciso recorrer a eles, com a ajuda dos xamãs, para que seja possível definir-se novamente como uma pessoa humana específica. Deste modo, a concepção dos enfeites corporais para os Mamaindê remete a uma teoria da pessoa e da instabilidade constitutiva do corpo humano, que é irredutível à teoria identitária do Estado simbolizada pela carteira de identidade. Tomar os enfeites corporais como uma espécie de carteira de identidade, como poderia sugerir à primeira vista a comparação feita pelo jovem mamaindê citada no início, é reduzir o seu significado e desconsiderar a concepção dos enfeites corporais própria dos Mamaindê. Para este grupo Nambiquara, conhecer os enfeites corporais de outros tipos de seres implica um regime de conhecimento que está baseado nas noções de alteridade e de transformação, mais do que nas ideias de identidade ou de representação.

\section{A carteira de identidade como ornamento corporal}

Minha hipótese é, como eu anunciei no início, a de que a comparação feita pelo jovem mamaindê entre os seus enfeites corporais e a carteira de identidade dos brancos indica que, para os Mamaindê, a carteira de identidade é um tipo de enfeite corporal e não o contrário. Neste sentido, o modo como os Mamaindê vêm se apropriando deste documento é semelhante ao modo como os xamãs se apropriam dos objetos dos mortos e dos espíritos em geral. Eu me arrisco a sugerir aqui que a carteira de identidade é pensada pelos Mamaindê como um objeto xamânico. De posse deste documento, os Mamaindê podem ser reconhecidos como semelhantes pela polícia que, como vimos, foi comparada pelo meu informante aos espíritos da floresta. O mesmo se passa com o xamã que, 
de posse dos enfeites dos mortos, passa a ser reconhecido como um semelhante por eles.

A carteira de identidade, assim como os ornamentos corporais usados pelos Mamaindê, é um índice das relações estabelecidas com a polícia. Longe de simbolizar uma identidade previamente definida, este documento torna possível um processo de transformação nos mesmos moldes daquele experimentado pelo xamã que, de posse dos enfeites dos mortos, passa a ser reconhecido por eles como um semelhante e pode, assim, ver o mundo como eles, ou melhor, passa ver o mundo deles. A carteira de identidade se torna, neste caso, um objeto indispensável para que os Mamaindê possam atravessar fronteiras e transitar nas cidades.

Algumas informações sobre a localização geográfica da aldeia Mamaindê são necessárias para que se entenda o meu argumento (ver Figura 1). Durante o período em que realizei meu trabalho de campo, os Mamaindê viviam em uma única aldeia (Posto Indígena Capitão Pedro), no extremo norte da Terra Indígena Vale do Guaporé (MT). A aldeia ficava a cerca de 30 quilômetros de distância da rodovia federal (BR 364) que liga os estados de Mato Grosso e Rondônia. Seguindo cerca de 80 quilômetros ao norte deste ponto da rodovia chega-se à cidade de Vilhena, em Rondônia. Partindo do mesmo ponto e seguindo 60 quilômetros em direção ao sul chega-se à cidade de Comodoro, em Mato Grosso. Os Mamaindê viviam, portanto, bem próximos da fronteira entre estes dois estados brasileiros e transitavam quase diariamente por este trecho da rodovia federal para irem tanto a Vilhena como a Comodoro. Nestas cidades, eles faziam compras, buscavam atendimento médico, visitavam parentes internados na Casa do Índio e recebiam auxílios de programas assistenciais do governo. O transporte geralmente era feito com uma caminhonete doada pela Funai.

Na rodovia federal, dois postos de fiscalização marcam a divisa entre os estados acima mencionados: o posto da polícia rodoviária e o posto da vigilância sanitária. Nestes pontos, há uma série de barreiras que obrigam os carros a diminuir a velocidade e, quando solicitados, os motoristas devem parar para que seus veículos sejam inspecionados pelos policiais, o que inclui um pedido para que mostrem seus documentos. Essa situação já foi vivida pelos Mamaindê inúmeras vezes. Ouvi muitas histórias sobre esse tipo de experiência, principalmente quando, na pequena caminhonete usada pelos Mamaindê, viajavam mais de 10 pessoas na caçamba, o que é proibido pelas normas nacionais de trânsito. Penso que, ao afirmar que "quando um branco perde a sua carteira de identidade a polícia o leva preso", meu informante provavelmente se referia à experiência, bastante comum para quem vive nesta região, de ser parado no posto da polícia rodoviária e ter que mostrar seus documentos. 
Figura 1 - Localização da Terra Indígena Vale do Guaporé, próxima à rodovia federal (BR 364), que liga as cidades de Comodoro e Vilhena e atravessa a divisa dos estados de Mato Grosso e Rondônia

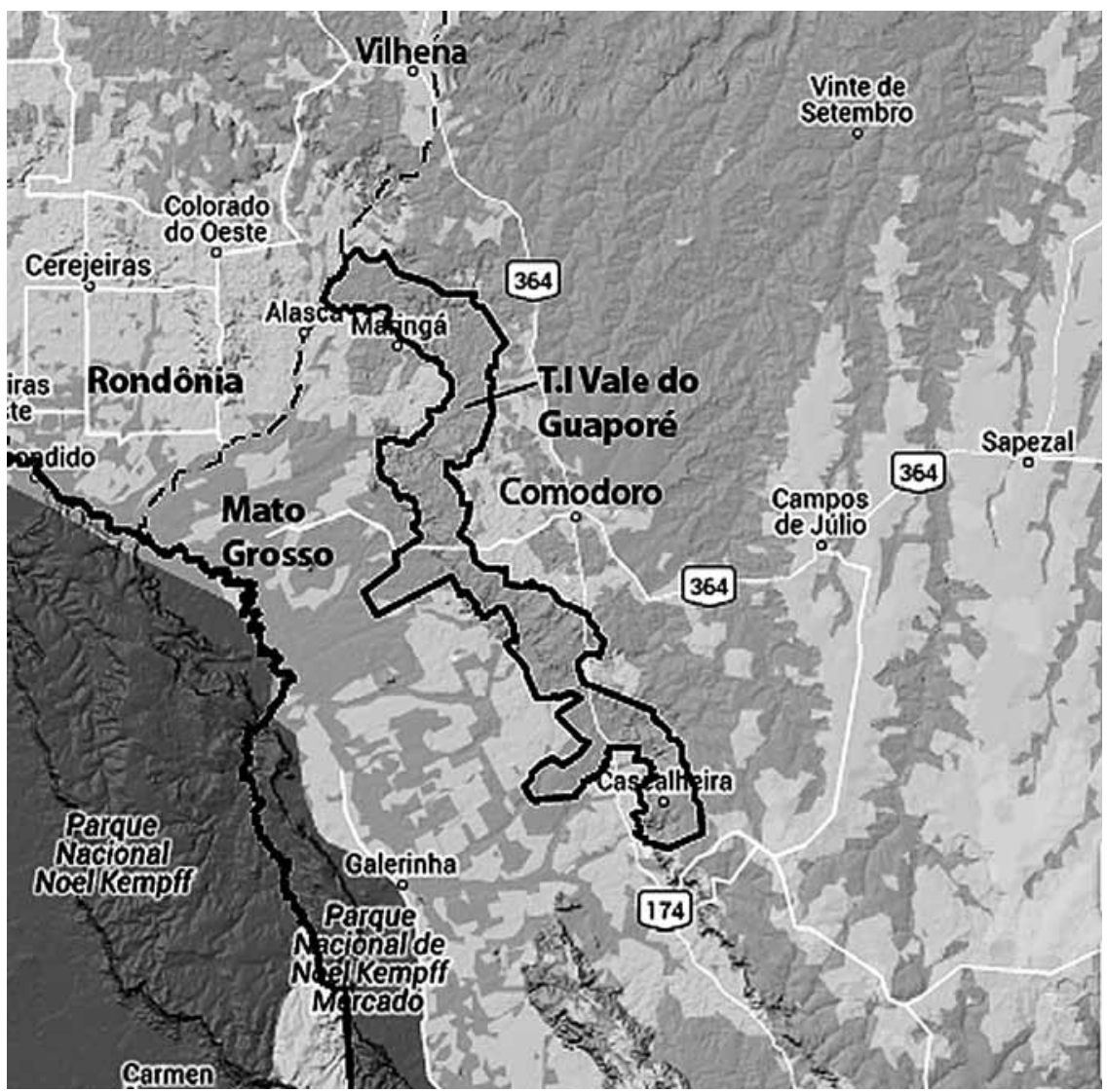

Os Mamaindê sabem, portanto, que a estrada que os leva à cidade é um território fiscalizado pela polícia, que exige os documentos de quem transita por ela e tem o poder de levar presos aqueles que não os têm para mostrar. Neste contexto, a carteira de identidade tem para os Mamaindê a mesma função que atribuímos ao passaporte: é um documento usado para se cruzarem fronteiras.

Não é incomum na Amazônia que certos objetos utilizados pelo xamã sejam descritos como documentos pelos povos indígenas que, muitas vezes, lhes atribuem uma função semelhante à do passaporte. Segundo Bilhaut (2007), a pedra usada pelos xamãs zaparo é frequentemente comparada aos documentos dos brancos. Assim a autora transcreve o relato de um sonho feito por uma mulher xamã que lhe descreve sua experiência onírica no mundo subterrâneo: 
Aí, dessa vez, você entra na montanha. Você entra no interior da montanha, você pode andar, falar, tudo. Se você não está bem preparado, eles não deixam passar para o interior da casa. Há uma casa no interior. Se você não está preparado, você quer entrar, eles te pedem seus documentos, você os tira, você os apresenta, mas você não apresentará documentos, você apresentará pedras. Depois, se você tem tudo, você vai passar. "Passagem proibida", se você não tem essas pedras, você não pode passar. É como no seu país, a fronteira é uma pedra muito grande. A fronteira é como uma porta (Bilhaut 2007:176).

Penso que a relação estabelecida entre os documentos e a pedra, tal como foi formulada pela xamã zaparo, não deve ser entendida como uma metáfora. Ela afirma que, no mundo subterrâneo, os documentos são pedras que, quando apresentadas pelo xamã, permitem-lhe cruzar fronteiras. Noto que este tipo de afirmação é semelhante à máxima perspectivista: "para o jaguar, o sangue é cauim" (Viveiros de Castro 2009:40-42). O problema aqui não é que a pedra do xamã seja como um documento, mas que, no mundo subterrâneo, os documentos são pedras. Não se trata, assim, de duas denominações para o mesmo objeto.

De acordo com Bilhaut (2007:176), a pedra dos xamãs zaparo, assim como os documentos, é um objeto usado para provar sua identidade nos contextos em que se cruzam fronteiras geopolíticas. Mas o que significa provar a identidade, neste caso? Se os objetos xamânicos, do mesmo modo que os documentos, permitem cruzar fronteiras, é interessante notar que o que se passa com o xamã é algo bem diferente daquilo que se passa quando usamos nosso passaporte para entrar em outro país. O documento do xamã não o identifica como um estrangeiro em territórios habitados por outras gentes, mas o torna um conterrâneo; ele não prova sua identidade, transforma-a. Dito de outro modo, ao invés de atestar uma identidade previamente definida, como faz o passaporte no contexto da relação entre os Estados modernos, a posse desse objeto-documento permite que o xamã seja reconhecido como um semelhante em terras estrangeiras. Cruzar fronteiras é, necessariamente, um processo de transformação.

A pintura corporal dos xamãs para os Marubo parece ter a mesma função que outros grupos indígenas atribuem aos objetos xamânicos e também é concebida como um passaporte. Descrevendo a noção de duplo para os Marubo, Cesarino conta o seguinte caso:

Por serem filhos dos vaká [duplos] das sucuris, os romeya [xamãs] Mechãpa e Venãpa (ou, antes, seus duplos) são também Pajés-Sucuri: podem entrar na Morada Subaquática e conversar com a gente de lá, justamente por possuírem os desenhos de sucuri, concebidos como uma espécie de passaporte para esse mundo (Cesarino 2012:62). 
Há ainda o caso de outro xamã que, segundo este autor, "tendo se formado a partir do broto de rapé-espírito (yove rome shãkõshki), acessa somente a Morada da Copa das Árvores: tem outra espécie de desenhos (invisíveis aos nossos olhos) em seu corpo, passaporte para o mundo arbóreo e não aquático" (Cesarino 2012:62).

É interessante notar que, assim como os colares dos Mamaindê, a pintura corporal dos xamãs marubo também pode ser invisível aos olhos dos não xamãs. ${ }^{13}$ São precisamente essas pinturas que os identificam com outros tipos de gente e é neste sentido que elas são concebidas como passaportes para outros mundos, como observa Cesarino.

Para os Mamaindê, como vimos, o próprio conhecimento xamânico pode ser descrito como a posse de muitos enfeites corporais que o xamã recebe dos espíritos dos mortos e do xamã que o iniciou. É a posse desses enfeites que permite que ele seja reconhecido como um semelhante pelos espíritos e possa entrar no mundo deles. Neste sentido, os enfeites são índices de relações estabelecidas com outros seres, mais do que símbolos identitários. Se eles, de certo modo, definem a identidade do xamã, é justamente porque indicam sua capacidade de transformação. ${ }^{14}$

Mas se os enfeites, as pinturas corporais ou os objetos xamânicos podem ser concebidos como documentos ou passaportes pelos povos ameríndios, há também casos em que os documentos são concebidos como objetos xamânicos. Em um interessante artigo sobre o poder dos objetos textuais na visão de mundo runa, Guzmán-Gallegos (2009) se detém no relato de um ataque xamânico no qual os documentos de identificação emitidos pelo Estado equatoriano desempenham um papel central. Trata-se do caso do diagnóstico dado por um xamã, membro da Tena Association of Shamans, para a doença que afligia uma senhora há anos. De acordo com o xamã, alguém havia capturado a pegada desta senhora e levado para o santuário de São Gonçalo, ${ }^{15}$ na província andina de Tungurahua. Para recuperar a pegada roubada, o xamã viajou junto com o filho da senhora adoentada até o local do santuário. A descrição do local feita pelo rapaz que acompanhou o xamã era semelhante àquela que os xamãs costumam fazer das suas viagens ao mundo dos espíritos após o consumo da ayahuasca. Quando finalmente chegaram ao santuário de São Gonçalo, uma mulher, "dona" de São Gonçalo, abriu a porta e perguntou aos dois homens qual deles era o xamã. Transcrevo a resposta do xamã, tal como relatada pela autora:

"Sou eu. Eu sou aquele que viu. Aqui está o meu cartão. Eu sou o dono do cartão. Eu faço parte do acordo ministerial". Quando ele mostrou seu cartão de identificação, no qual seu nome e número do cartão estavam escritos, ela os 
deixou entrar e os conduziu até uma sala de espera, onde ela os convidou a se sentarem (Guzmán-Gallegos 2009:221).

Guzmán-Galegos observa que, para se identificar como xamã e entrar no santuário, o xamã runa "imediatamente associou sua capacidade de ver como um xamã runa à sua posição de dono de uma carteira de identificação. A origem da carteira de identificação também é claramente afirmada como tal: ela é o produto de um acordo ministerial". A autora acrescenta que, de acordo com a explicação de seu informante, "sem esse documento, eles não teriam podido entrar na casa de São Gonçalo. Foi por causa do documento que a dona do santo os convidou a entrar" (2009:227-8).

A carteira de identificação apresentada pelo xamã runa é um documento emitido pelo Ministério do Bem-Estar Social aos membros de associações reconhecidas pelo governo do Equador. No caso descrito por Guzmán-Gallegos, a carteira de identificação do xamã é que lhe permite ter acesso ao mundo de São Gonçalo que, por sua vez, é associado ao mundo dos espíritos, tal como ele é descrito pelos xamãs. Noto que este documento emitido pelo Estado para os membros de uma associação xamânica torna-se, ele mesmo, um objeto xamânico. Assim como os colares do xamã mamaindê, a pedra do xamã zaparo e a pintura corporal do xamã marubo, comparados pelos próprios índios aos documentos, a carteira de identificação do xamã runa também é concebida como um objeto que o permite cruzar fronteiras.

No entanto, o caso analisado por Guzmán-Galegos tem singularidades interessantes. De acordo com esta autora, diferentemente de outros objetos xamânicos, a carteira de identificação do xamã runa tem um poder limitado. Ela permite que o xamã entre na casa de São Gonçalo e veja o que se passou com a vítima do ataque xamânico, mas não lhe permite atuar lá dentro. Neste caso, apenas a "dona" de São Gonçalo pode devolver a pegada roubada da vítima, o que impede o xamã de efetuar a cura. Para esta autora, isto se deve ao poder agentivo atribuído pelos Runa a este documento, que é diferente daquele atribuído a outros objetos xamânicos. Ela observa que:

Em contraste com as pedras xamânicas, não há nenhuma relação de colaboração entre a carteira de identificação e o xamã. Tampouco a carteira de identificação facilita a identificação entre o xamã e a dona de São Gonçalo. No mundo espiritual de São Gonçalo, ver não implica adotar o ponto de vista dos espíritos ou se tornar como eles (Guzmán-Gallegos 2009:230).

A autora argumenta, assim, que o significado atribuído pelos Runa aos documentos escritos aponta para os limites da atuação dos Runa no contexto 
das relações assimétricas historicamente estabelecidas com o Estado e a Igreja. Tais relações incluem a inserção dos Runa na burocracia estatal e a sua experiência com a Igreja Católica, ambas caracterizadas por mecanismos de controle baseados na produção de documentos escritos.

Alguns trabalhos recentes sobre o valor atribuído aos documentos escritos pelos povos ameríndios enfatizam o caráter assimétrico das relações estabelecidas com o Estado como um elemento fundamental para explicar o poder conferido a esses objetos (Allard 2012; Gordillo 2006). A análise de Gordillo (2006) para o caso dos Toba e Wichi do Chaco argentino é interessante. Este autor sugere que o valor atribuído por esses grupos indígenas à carteira de identidade se deve a um passado de exclusão, no qual eles não tinham acesso a este documento, uma vez que não eram reconhecidos pelo Estado como cidadãos argentinos. Neste caso, é a relação com o Estado, mais especificamente o não reconhecimento dos povos indígenas pelo Estado argentino, que explica o valor atribuído aos documentos por esses povos.

Segundo Gordillo, no início do século XX, a colonização do interior do Chaco argentino por fazendeiros e o avanço das instituições estatais impuseram sérios limites à mobilidade das populações indígenas nesta região. Os índios em trânsito eram vistos como uma ameaça pelos militares e pelas autoridades locais, que exigiam que eles produzissem documentos escritos atestando seu "bom comportamento". A maior parte desses documentos era escrita à mão por oficiais do Estado, ou por pessoas influentes, como missionários, comerciantes e fazendeiros, e era chamada de "passaportes". A posse desses documentos permitia aos grupos indígenas transitarem pelo violento território do Chaco sem serem mortos pelos soldados do exército.

Gordillo observa, no entanto, que "algumas pessoas lembram de sua falta de documentos como uma condição ontológica que, aos olhos dos agentes do Estado e dos fazendeiros, autorizava uma punição violenta". Um homem wichi descreveu este período da seguinte forma:

Nós não tínhamos "documentos", é por isso que eles nos matavam. Eles têm uma lei que diz que aqueles que não têm "documentos" não valem nada; que eles são como animais, como coelhos. É por isso que os mestiços nos matavam. Eles nos matavam (Gordillo 2006:168).

Para Gordillo o valor atribuído pelos índios aos documentos escritos é o resultado de uma experiência contraditória: eles eram privados dos documentos de identidade oficiais porque não eram reconhecidos como cidadãos argentinos pelo Estado, mas precisavam produzir outros tipos de documentos para saírem da condição de "selvagens" que a ausência de documentos 
lhes imputava. Mas é interessante notar neste caso que se, para os brancos (agentes governamentais, soldados, fazendeiros), os "passaportes" ou "certificados de boa conduta" eram uma forma de conviver com os índios sem, no entanto, ter que reconhecê-los como congêneres (argentinos), para os índios, como fica claro no relato do homem wichi, os "documentos" garantiam a convivência com os brancos na medida em que lhes permitiam mudar de estatuto ontológico: eles deixavam de ser vistos e, portanto, mortos como animais e podiam ser reconhecidos como semelhantes pelos soldados do exército. Neste sentido, os documentos lhes permitiam transitar pelo Chaco porque lhes permitiam mudar de identidade quando tinham de interagir com os brancos que passaram a ocupar a região.

Gordillo ressalta a diferença entre o significado atribuído aos documentos pelo Estado e aquele atribuído pelos índios. Segundo ele, os Toba e Wichí viam os documentos como objetos cuja potência emanava de sua materialidade, mais do que das relações sociais e das convenções implicadas na sua produção, e agiam como se a simples posse do documento fosse suficiente para produzir o efeito desejado. ${ }^{16}$

Este autor sugere comparar o que ele chama de fetichização dos documentos pelos povos indígenas do Chaco com o fetichismo da mercadoria analisado por Marx. Para Gordillo, se o fetichismo da mercadoria consiste em um modo de produção de valor que oculta as relações sociais implicadas na sua produção, no caso do fetichismo dos documentos ao qual ele se refere o que está em jogo parece ser justamente a conexão entre os documentos e o Estado. Em suas palavras:

Enquanto no fetichismo da mercadoria a ligação entre a mercadoria e seu produtor tende a ser apagada, a fetichização dos documentos de identidade depende, ao menos em um certo grau, de manter uma conexão entre esses objetos e o Estado. Em resumo, enquanto o fetichismo da mercadoria cria a aparência de objetos potentes, desancorados, destacados do trabalho, o fetichismo dos documentos de identidade cria a aparência de objetos potentes ancorados na produção do Estado (Gordillo 2006:163).

A noção de fetiche, tal como usada por Gordillo, procura enfatizar a importância que os povos indígenas do Chaco davam à materialidade do objeto que, segundo ele, absorvia o valor criado pelas relações sociais engendradas na sua produção (Gordillo 2006:164). No caso dos Mamaindê, no entanto, a noção de fetiche não parece adequada para caracterizar o valor atribuído aos documentos justamente por supor uma teoria da materialidade que é incompatível com as concepções dos Mamaindê sobre a relação entre 
material/imaterial, ou visível/invisível. Como argumentei, neste contexto etnográfico, o que torna um objeto visível ou invisível não é uma característica intrínseca a ele, mas a capacidade visual do observador. Deste modo, a oposição material/ imaterial parece ser mais a consequência de uma posição perspectiva do que um atributo substantivo do objeto.

Se a ênfase na materialidade do documento de certa forma oculta as relações sociais implicadas na sua produção, como observou Gordillo, devo notar que para os Mamaindê, como vimos, os documentos são objetos poderosos precisamente porque indicam relações, ao invés de ocultá-las. Além disso, são as relações, e não o documento em si, que definem o que é material/imaterial. Portanto, como procurei demonstrar até aqui, para os Mamaindê, os documentos, assim como os enfeites corporais, são índices das relações de alteridade que constituem a pessoa neste contexto etnográfico, e não símbolos identitários ou objetos que têm poder em si mesmos. O poder atribuído à carteira de identidade, neste caso, deriva do fato de ela indicar a capacidade daquele que a possui de adotar outro ponto de vista, na medida em que lhe permite ser reconhecido como um semelhante pela polícia, daí sua associação com os objetos xamânicos. Penso que seria mais produtivo descrever o valor atribuído aos documentos pelos povos indígenas em termos de "abdução de agência", como sugere Gell (1998) para pensar os objetos de arte. Dito de outro modo, ao menos no caso dos Mamaindê, os documentos estariam mais próximos dos objetos de arte do que da mercadoria.

Em um artigo sobre a introdução da escrita entre os Piro da Amazônia peruana, Gow (1990) conta a história de Sangama, tido como o primeiro homem piro a ler, e mostra como, neste caso, os papéis escritos estavam longe de serem concebidos como meros objetos. De acordo com este autor, Sangama recolhia os jornais descartados pelos patrões brancos para quem os Piro trabalhavam no início do século XX e os lia. Ele dizia saber ler o papel argumentando que "[...] O papel tem um corpo; Eu sempre a vejo... Ela tem lábios vermelhos com os quais ela fala" (Gow 1990:92-3). Sangama lia com olhos de xamã.

A capacidade de enxergar os objetos como sujeitos, atribuindo-lhes uma agência própria ou relacionando-os a outros tipos de seres, constitui uma das principais características dos xamãs na Amazônia e define o próprio ideal de conhecimento nesta região. Conforme observou Viveiros de Castro:

Tal ideal é, sob vários aspectos, o oposto polar da epistemologia objetivista favorecida pela modernidade ocidental. Nesta última, a categoria do objeto fornece o telos: conhecer é objetivar; é poder distinguir no objeto o que lhe é intrínseco do que pertence ao sujeito cognoscente [...]. A forma do Outro é a 
coisa. O conhecimento xamânico é, ao contrário, uma operação de subjetivação: "conhecer é personificar, tomar o ponto de vista daquilo que deve ser conhecido [...] visa um "algo" que é um "alguém", um outro sujeito ou agente. A forma do Outro é a pessoa (Viveiros de Castro 2002 [1996]:358).

Neste sentido, os xamãs foram qualificados como mediadores, tradutores ou diplomatas da cosmopolítica ameríndia (Carneiro da Cunha 1998; Viveiros de Castro 2002; Sztutman 2012). Gostaria de notar aqui que os seus objetos, muitas vezes descritos por eles próprios como documentos ou passaportes, não são símbolos identitários, nem representações do seu poder, mas a matéria-prima a partir da qual este poder é produzido, na medida em que apontam para as relações que eles estabelecem com outros tipos de seres e que passam a constituí-lo como um ser múltiplo e diferente de si mesmo.

Ao relacionar o valor atribuído aos documentos escritos pelos povos ameríndios com o regime de conhecimento xamânico na Amazônia, não estou sugerindo desvinculá-lo do contexto histórico particular que marcou a inserção dos diferentes grupos indígenas no aparato burocrático dos Estados nacionais caracterizado por relações claramente assimétricas. É evidente que nos casos mencionados acima há diferenças históricas importantes. No entanto, o que pretendi demonstrar até aqui foi que, ao menos para os Mamaindê, os documentos, em determinados contextos de interação com os brancos, têm o mesmo valor que os ornamentos possuem nos contextos de interação com outras figuras de alteridade e que, de certo modo, é esta experiência que torna os documentos, particularmente a carteira de identidade, inteligíveis para os Mamaindê. Parece-me, assim, que a importância atribuída à carteira de identidade neste contexto etnográfico, antes de expressar o caráter assimétrico das relações estabelecidas com o Estado, apontaria, como sugeriu Viveiros de Castro (2011), para uma concepção nativa do Estado como um tipo de espírito.

\section{Espíritos e polícia}

Gostaria de me ater agora à segunda comparação estabelecida pelo meu informante, aquela entre os espíritos da floresta e a polícia. Foi um comentário de Viveiros de Castro (2011) que me chamou a atenção para o fato de que a relação estabelecida pelos Mamaindê entre os seus enfeites e a carteira de identidade era, sobretudo, uma relação entre polícia e espírito, ao sugerir uma analogia entre os perigos da sujeição envolvidos nos encontros sobrenaturais frequentemente descritos pelos povos ameríndios e a experiência 
do indivíduo moderno perante o Estado. O medo produzido pelo encontro com os espíritos na floresta seria equivalente ao medo que sentimos em um encontro com a polícia - em ambos os casos a ameaça é perder a posição de sujeito e se tornar objeto da perspectiva do outro. "Como os espíritos, a polícia está sempre à espreita da chance de transformar alguém em ninguém, para depois fazê-lo desaparecer" (Viveiros de Castro 2011:902).

Os encontros sobrenaturais com espíritos na floresta seriam, como argumenta Viveiros de Castro, “[...] um tipo de protoexperiência indígena do Estado, ou seja, uma premonição da experiência propriamente fatal de se descobrir cidadão de um Estado..." (2011:904). A experiência de incerteza e desamparo que sentimos quando nos vemos diante de encarnações do Estado ou, no caso dos índios, de espíritos equivale, de certo modo, a um "desaparentamento". Conforme observa este autor (2011:905), se estabelecermos que o Estado moderno é a ausência de parentesco, o encontro com espíritos na floresta, comparados pelo jovem Mamaindê à polícia, também desfaz o parentesco. A pessoa passa a acompanhar esses espíritos, adotando a perspectiva deles, deixando assim de reconhecer os seus próprios parentes.

Devo notar que os Mamaindê não são os únicos a comparar diretamente os espíritos à polícia. Voltemos às etnografias já citadas. De acordo com Guzmán-Gallegos (2009:224), as pedras usadas pelo xamã runa contêm espíritos ou almas que são liberados e comandados pelo xamã. Estas pedras também costumam ser descritas como "soldados" que o protegem. Tais objetos possuem agência própria e devem ser constantemente domesticados pelo xamã sob o risco de atuarem contra a sua vontade. A autora contrasta o poder agentivo atribuído pelos Runa às pedras xamânicas àquele atribuído aos documentos escritos, concluindo que estes últimos seriam objetos com menos agência ou sem agência própria, o que explicaria o fato de não serem tão eficazes nos processos de cura, como vimos acima.

Segundo Cesarino (2008:141-143), os Marubo chamam de "polícia" alguns espíritos agressivos, assassinos, situados nas cidades. Esses espíritos são originários de matadores ou do espírito da cachaça e encostam nas pessoas, tornando-as insensatas. Eles interrompem o parentesco, jogam as pessoas umas contra as outras. Em um mito de origem dos brancos, eles são associados a policiais bravos e a espíritos da cidade descritos como estrangeiros prendedores, um tipo de polícia. Os Marubo dizem que nas aldeias os xamãs controlam constantemente o assédio dos espectros dos mortos que fazem mal aos vivos, mas que nas cidades não são capazes de controlar o assédio desses espíritos-policiais-brancos. Ao se lembrar do início de suas visitas às cidades, Lauro Marubo lamenta: "naquela época, a cidade era boa, era bom viver na cidade. Naquela época, podíamos ficar nas cidades sem documentos" (Cesarino 2008:141). 
Há ainda outros exemplos etnográficos deste tipo de associação estabelecida pelos povos ameríndios entre os espíritos e a polícia ou os soldados do exército. Os Maxacali, povo falante de uma língua do tronco Macro-Jê estudado por Tugny, se referem a uma categoria de espíritos chamada de tatakox como "polícia federal" (Tugny 2008:54-55). Este tipo de espírito tem a função de cuidar do bom apodrecimento do cadáver e evitar que ele se transforme em um tipo de espírito/espectro monstruoso (inmõxã) que ameaça os vivos. Segundo esta autora, caso o cadáver se transforme em inmõxã, é este espírito (tatakox) dito "polícia federal" quem irá domá-lo. Os Maxacali dizem também que os brancos nasceram dos inmõxãs (espírito/espectro) dos cadáveres abandonados nas aldeias antigas. Tugny nos conta ainda que, quando os Maxacali viajam para Belo Horizonte,

Estão sempre a escrutar o jardim do Hospital Militar, onde alguns deles assistiram aos assaltos furiosos do "inmõxã" contra as grades até que fosse controlado pelo seu dono, um soldado da Polícia Militar que lá trabalha, e levado para a sua casa, uma capela florida onde jaz uma imagem de Nossa Senhora (Tugny 2008:56).

Ao contrário dos espíritos-policiais referidos pelos Marubo, que parecem ser associados ao espectro dos mortos, os espíritos descritos como "polícia federal" pelos Maxacali são espíritos que tentam afastar ou controlar o estado de descontrole e cólera associado ao espectro dos mortos que não seguem seu destino póstumo e permanecem ameaçando os vivos. ${ }^{17}$

Não posso deixar de mencionar também a intrigante categoria de xondáro (soldado) dos Mbya-Guarani, cuja complexidade escapa aos limites deste trabalho. Em um comentário sobre a cosmografia mbya-guarani, Pissolato observa que alguns seres do panteão das divindades guarani teriam suas moradas em regiões celestes. Há, segundo ela:

[U]ma noção geral de que as divindades teriam seus "trabalhos" ou habilidades específicas, desenvolvidos a certa hora do dia ou da noite, no que são sempre ajudados por auxiliares que controlam. Estes últimos podem ser ditos Nhanderu rembiguái ("servos" de Nhanderu), yvyra'ija (termo respeitoso vinculado na maior parte das vezes à colaboração na reza) ou xondáro ("soldados" que, fora do contexto da reza, são representados como uma espécie de "polícia" que faria cumprir as determinações de um deus) (Pissolato 2007:305).

Gostaria de chamar a atenção aqui para a ambiguidade constitutiva dessa categoria de espíritos-policiais ou "soldados" que ora protege/auxilia, ora captura aqueles que se arriscam a se relacionar com eles. Em um comen- 
tário sobre a relação entre os xamãs e seus espíritos auxiliares na Amazônia, muitas vezes descrita como uma adoção, Fausto (1999) ressalta justamente a ambiguidade que a caracteriza: "já que nunca se sabe exatamente quem adota quem, nem quem controla quem" (Fausto 1999:938).

Em agosto de 2005 presenciei um acontecimento que passou a ser frequentemente mencionado pelos Mamaindê quando eles tentavam me explicar como atuavam os espíritos e os perigos que envolviam as relações estabelecidas com eles. O modo de atuação da polícia foi, neste caso, mais do que uma metáfora para qualificar este tipo de relação. Naquela ocasião, um homem mamaindê foi preso em Vilhena depois de ter comprado munição para caçar sem apresentar os documentos necessários: sua carteira de identidade e o registro da arma. O caso ocorreu na época em que o governo brasileiro realizava um plebiscito para decidir, por meio do voto popular, se a venda de armas de fogo deveria ou não ser proibida no país, o que certamente intensificou a fiscalização sobre a venda de armas e munição.

Quando a notícia da prisão deste homem chegou à aldeia, seus parentes, bastante preocupados, decidiram ir até a cidade para libertá-lo. Antes, porém, pintaram-se de preto com uma tinta feita com carvão (pintura de guerra) e enfeitaram-se com vários tipos de enfeites (colares, perneiras e braçadeiras de algodão, pingentes e cocares de penas de tucano). Segurando flechas e bordunas, cantaram músicas de guerra e decidiram aguardar o carro da Funasa que chegaria à aldeia naquele dia para trazer de volta algumas pessoas que estavam internadas na Casa do Índio de Vilhena. Quando o carro chegou, o motorista se viu obrigado a levar para Vilhena quase todos os jovens da aldeia que, em um piscar de olhos, amontoaram-se sobre a carroceria da pequena caminhonete. Aqueles que não conseguiram subir no carro seguiram de bicicleta até a estrada (BR364) e depois de ônibus para a cidade.

Chegando lá, os Mamaindê dirigiram-se à delegacia, onde cantaram por algumas horas músicas de guerra ('ahn'sadu, música de ficar com raiva) e músicas de xamã (waninso'gã hainsidu) e exigiram a presença do delegado. Assim que o delegado se aproximou, dois rapazes o seguraram rapidamente, retiraram o colete da polícia civil que ele estava usando e pintaram o seu rosto de preto. Os policiais que estavam por perto, surpreendidos, não reagiram. Os dois jovens mamaindê disseram então que só soltariam o delegado quando ele libertasse o parente deles que estava preso. Todos entraram na delegacia e, algum tempo depois, o delegado mandou que soltassem o homem que havia sido preso. A essa altura, muita gente se aglomerava na frente da delegacia, incluindo um repórter da TV local enviado para registrar o acontecimento (ver figura 2). 
Quando saiu da prisão, o homem deu uma entrevista e, contrariando todas as expectativas (pelo menos as minhas), disse que estava muito satisfeito com o tratamento que havia recebido. Afirmou ter sido tratado como um parente, enfatizando que lhe deram comida. Logo em seguida, os seus parentes aproximaram-se dele e, segurando-o firmemente pelos braços, lhe disseram: "nós é que somos os seus parentes! Você foi preso, mas nós viemos aqui para te soltar. Seus irmãos estavam muito preocupados, olhe bem para nós, nós somos seus parentes, não eles!".

Figura 2 - Notícia publicada no Jornal Extra de Rondônia, 5 de agosto de 2005

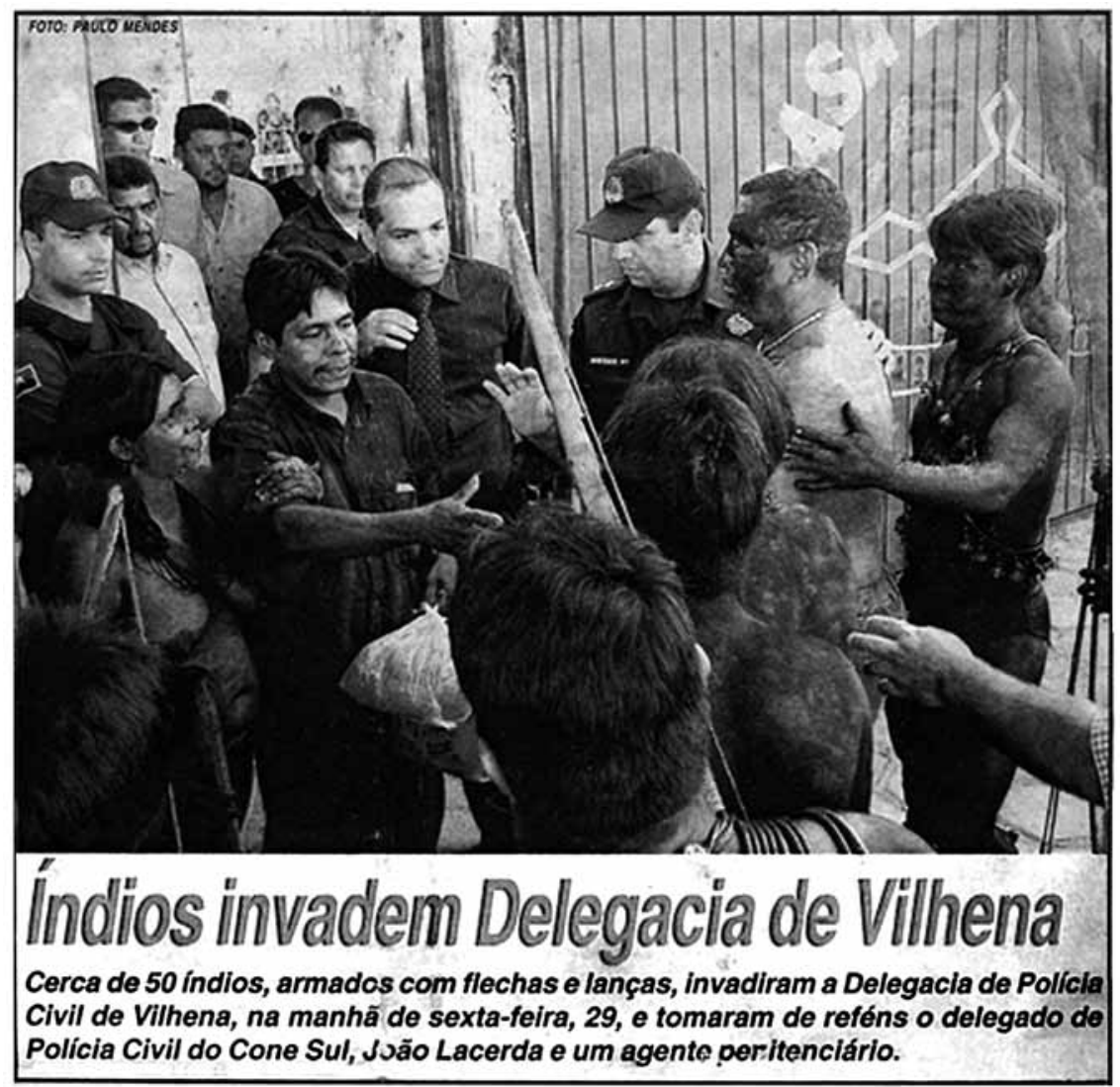


Depois disso, quando os Mamaindê tentavam me explicar a atuação dos espíritos, tal como era cantada pelos xamãs nas músicas de cura, sempre se reportavam a este caso. Segundo eles, durante as sessões de cura, os espíritos dos mortos vão buscar, dentro de cavernas ou de buracos na floresta, o espírito do doente que foi roubado pelos espíritos do mato, do mesmo modo que eles fizeram ao buscar o parente que havia sido preso na cidade. Quando o xamã, auxiliado pelos espíritos dos mortos, finalmente encontra o espírito do doente, ele já está sem os seus enfeites corporais, que foram todos roubados. Por este motivo, o doente em geral não quer mais voltar, pois não os reconhece mais. Cabe aos espíritos dos mortos, juntamente com o xamã, dizer ao doente quem são os seus verdadeiros parentes, contando que estão todos muito tristes, com saudades, convencendo-o, assim, a voltar com eles para a aldeia, do mesmo modo que os Mamaindê fizeram com o homem no momento em que foi libertado. Só então os espíritos dos mortos retornam carregando o espírito do doente, que é referido nas músicas de cura como "um enfeite" (wasain'du).

Os espíritos dos mortos anunciam ainda que têm mais enfeites para dar ao xamã e dizem que estão com fome, porque foram muito longe para resgatar as "coisas/espírito" (wasain'du) do doente. Pedem, então, a comida que foi preparada para eles e fazem comentários sobre ela, indicando que ficaram satisfeitos. Neste ponto, os Mamaindê acrescentaram que, quando voltaram para a aldeia trazendo o homem que havia sido preso pela polícia na cidade, comportaram-se como os espíritos dos mortos, enfeitando-se e pedindo às mulheres que fizessem bastante chicha e comida para que todos pudessem cantar e comer juntos, mostrando ao homem recém-libertado, agora novamente enfeitado, que ele estava com os seus verdadeiros parentes.

Se a polícia é um tipo de espírito, o perigo do encontro com a polícia nas estradas ou na cidade é o de ser capturado por ela, separado dos seus parentes. Assim, a pessoa se torna objeto da perspectiva de Outro, como notou Viveiros de Castro (2011). Neste tipo de encontro há sempre a possibilidade de uma transformação indesejada, que também pode ser descrita como um desaparentamento; a pessoa afetada deixa de reconhecer seus próprios parentes, tornando-se parente de Outros.

Para os Mamaindê, ter a carteira de identidade para mostrar para a polícia é sobretudo ter a possibilidade de ser reconhecido como um semelhante por ela, do mesmo modo que, de posse dos enfeites dos espíritos, o xamã passa a ser reconhecido como um semelhante e pode, desta maneira, se relacionar com eles, ou entrar em seu mundo sem ser capturado. A carteira de identidade é, neste sentido, um operador de relações. Ela amplia as relações daquele que a possui para além do universo local da sociabilidade 
e do parentesco, tornando os Mamaindê semelhantes aos brancos-policiais nos contextos em que devem interagir com eles. Deste modo, diante da experiência do medo e do "desaparentamento" que, como notou Viveiros de Castro, caracteriza tanto os encontros com espíritos descritos pelos índios como a experiência do indivíduo moderno perante as encarnações do Estado, o modo como os Mamaindê se apropriam da carteira de identidade consiste justamente em uma tentativa de não perder a posição de sujeito em uma relação, na medida em que lhes permite mudarem de identidade e serem reconhecidos como sujeitos pelos policiais-brancos.

Os Mamaindê costumam aconselhar quem se depara sozinho com uma sucuri na floresta a lembrar-lhe de sua condição humana dizendo-lhe o seguinte: "meu avô, eu também sou gente" ou, como formulou um xamã, "meu avô, olhe bem, eu sou seu parente". Deste modo, evita-se uma transformação indesejada. ${ }^{18}$ Penso que, ao se encontrarem com a polícia nas estradas ou nas cidades por onde os Mamaindê transitam quase com a mesma frequência com que transitam pela floresta, eles devem apresentar a carteira de identidade com o mesmo intuito: o de evitar perder a posição de sujeito na relação com os brancos.

\section{Conclusão}

A comparação feita pelo jovem mamaindê entre os seus enfeites corporais e a carteira de identidade é semelhante àquela feita pela xamã zaparo entre as pedras xamânicas e os documentos. Se, como explicou a xamã zaparo, no mundo subterrâneo os documentos são pedras, é possível imaginar que para os Mamaindê, nas cidades, seus enfeites sejam documentos. A comparação sugerida pelo meu informante não deve, portanto, ser entendida como uma metáfora. Não se trata de representações diferentes para o mesmo objeto, mas de mundos diferentes.

Sugiro pensar a comparação feita pelo jovem mamaindê como um equívoco, no sentido conferido ao termo por Viveiros de Castro (2004) para se referir a situações que colocam em evidência diferentes ontologias, ou mundos, mais do que diferentes representações sobre o mundo. De acordo com Viveiros de Castro,

O problema para o perspectivismo indígena não é portanto o de descobrir o referente comum (o planeta Vênus, digamos) para duas representações diferentes ("estrela da manhã" e "estrela da tarde", digamos). Pelo contrário, o problema é o de tornar explícita a equivocação implicada em imaginar que, quando o 
jaguar diz "cerveja de mandioca", ele está se referindo à mesma coisa que nós (i.e, uma bebida gostosa, nutritiva e inebriante). Em outras palavras, o perspectivismo supõe uma epistemologia constante e ontologias variáveis, as mesmas representações, e outros objetos, um único significado e múltiplos referentes (Viveiros de Castro 2004:6-7).

Apostando na ideia de que a carteira de identidade é um tipo de enfeite corporal, e não o contrário, penso que, embora os Mamaindê não tenham formulado desta forma, é possível imaginar que a carteira de identidade seja o enfeite/alma dos brancos, aquilo que os brancos dão a ver de si mesmos quando se relacionam com os Mamaindê e aquilo que os Mamaindê devem mostrar para serem reconhecidos por eles como semelhantes. Sugiro, assim, que a carteira de identidade, tal como é concebida pelos Mamaindê, poderia ser descrita como uma carteira de alteridade, se imaginássemos um mundo onde os documentos de identidade são índices da capacidade de transformação daqueles que os possuem ao invés de símbolos identitários. Um mundo onde o documento de identidade, ao invés de transformar a pessoa em um cidadão dessubjetivado diante das representações do Estado, desfazendo as relações de parentesco, ao contrário, amplia a rede de parentesco para além do universo da sociabilidade local, incluindo os brancos que vivem nas cidades.

Gostaria de terminar me reportando ao sonho que uma mulher mamaindê me contou. O sonho não se refere exatamente à carteira de identidade, mas aos documentos escritos de um modo geral. Ela me disse que durante o sonho esteve na aldeia dos mortos. Lá, as casas eram todas parecidas e as árvores enfileiradas, como na rua principal de Vilhena. Em uma dessas casas morava um xamã muito poderoso chamado Jesus, que distribuía senhas para os doentes que esperavam para serem atendidos do lado de fora, exatamente como acontece no posto de saúde de Vilhena, onde os Mamaindê costumam ir para consultas médicas. Ela não pegou a tal senha, mas viu Jesus pela janela, de relance, e concluiu que, se tivesse entrado na casa dele sem aquele papel, certamente teria morrido.

Recebido em 06 de julho de 2015

Aprovado em 10 de outubro de 2015

Joana Miller é professora do Departamento de Antropologia da Universidade Federal Fluminense. E-mail: <miller.joana@gmail.com> 


\section{Notas}

* Agradecimentos: versões preliminares deste artigo foram apresentadas no seminário do Nuti/Nansi, no $54^{\circ}$ Congresso Internacional dos Americanistas (Viena), no seminário Encontros no Gragoatá da UFF e em um seminário no Museu Nacional/ UFRJ. Agradeço a todos que fizeram comentários nessas ocasiões, particularmente a Marcio Goldman, Tânia Stolze, Ovídio Abreu, Luisa Elvira Belaunde, Rupert Stasch, Carlos Fausto, Aparecida Vilaça, Luiz Costa, Harry Walker e Casey High. Agradeço especialmente a Eduardo Viveiros de Castro pelos comentários feitos à minha tese de doutorado e que me levaram a escrever este artigo. Agradeço ainda ao jornal Extra de Rondônia por autorizar o uso da fotografia que reproduzo aqui.

${ }^{1}$ Realizei 13 meses de trabalho de campo com os Mamaindê, entre os anos de 2002 e 2005, na Terra Indígena do Vale do Guaporé (MT).

${ }^{2}$ Ver Turner (1992) para uma interpretação semelhante para os Kayapó.

${ }^{3}$ Em trabalhos anteriores (Miller 2005, 2009) apresentei uma descrição detalhada dos enfeites corporais usados pelos Mamaindê, especialmente do colar de contas de tucum.

${ }^{4}$ Devo lembrar que nas últimas décadas alguns etnólogos têm enfatizado precisamente a relação entre os processos de fabricação de adornos corporais e de outros artefatos pelos povos ameríndios e as concepções cosmológicas desses povos (van Velthem 2003; Guss 1990; Gallois 1992; Barcelos Neto 2002; Lagrou 2007).

${ }^{5}$ Vidal (1992:146) e Lagrou (2007:308), escrevendo sobre os Xikrin e os Kaxinawa, respectivamente, notaram que o ato de enfeitar e pintar as crianças também está associado à proteção, ao afeto e ao cuidado.

${ }^{6}$ De acordo com os Mamaindê, o rompimento dos enfeites corporais pode fazer adoecer não só aquele que teve os seus enfeites rompidos, mas também os seus parentes, particularmente seus irmãos e filhos. Neste caso, fica evidente que os enfeites constituem a pessoa, conectando-a a um grupo de parentes de tal modo que o que afeta os seus próprios enfeites afeta também os seus parentes. Algo semelhante já foi descrito para as práticas relacionadas à comensalidade na Amazônia indígena. Comer junto ou abster-se de comer determinados alimentos é um importante indicador das relações de parentesco e da identidade de perspectivas (Gow 1991; Vilaça, 2002; Fausto 2007). Sahlins (2013:44-53) notou que esse caráter transpessoal do parentesco é amplamente difundido.

${ }^{7}$ Segundo Colpron (2004), para os Shipibo, o corpo do doente, aos olhos do xamã, se revela grotesco, enfeitado com os enfeites da espécie agressora que o xamã deve então retirar para efetuar a cura. Neste caso, noto que a doença também é concebida como um processo de transformação corporal caracterizado pelo uso de enfeites de 
outras espécies de sujeitos. Em um trabalho mais antigo, Gebhart-Sayer (1986) falava em uma "terapia estética" entre os Shipibo. Neste caso, a cura xamânica implicava refazer os desenhos invisíveis que cobriam o corpo do paciente.

${ }^{8}$ Viveiros de Castro $(2004: 4,7)$ notou que o mito remete a um estado caracterizado pela perfeita transparência, no qual as dimensões espiritual e corporal de cada ser ainda não se eclipsavam umas às outras. $\mathrm{O}$ mito descreve justamente como este estado de transparência foi suplantado por uma relativa opacidade em que corpo e alma passaram a funcionar alternadamente como figura e fundo em relação um ao outro. O xamã seria, neste sentido, alguém capaz de enxergar os corpos em seu estado originário de transparência.

${ }^{9}$ A impossibilidade de se definir a si mesmo sem recorrer à perspectiva de Outro também possui desdobramentos sociológicos neste contexto etnográfico. Os nomes dos grupos Nambiquara nunca são autodesignações, mas nomes dados por outros grupos e são, muitas vezes, termos pejorativos. Em sua dissertação sobre os Wanarisu, um grupo Nambiquara situado ao sul do Vale do Guaporé (MT), Fiorini (1997:59) conta que, depois de insistir muito para que o seu informante lhe dissesse o nome do seu próprio grupo, ele recebeu a seguinte resposta: o único nome que ele poderia atribuir ao seu próprio grupo seria o nome atribuído à aldeia dos mortos.

${ }^{10}$ Escrevendo sobre o parentesco na Amazônia, Vilaça (2002) explorou a noção de alteridade interna à consanguinidade, enfatizando que as relações estabelecidas no exterior do grupo local são parte constitutiva das relações de parentesco neste contexto etnográfico. Ela argumenta assim que para os povos ameríndios a criação do parentesco entre humanos não pode ser dissociada da relação com subjetividades não humanas. No caso dos Mamaindê, a relação que se estabelece com os espíritos dos mortos é fundamental para definir a identidade dos vivos e tem sua expressão material nos enfeites corporais usados pelos Mamaindê.

${ }^{11}$ Este mesmo estado de solidão e desamparo também caracteriza as meninas em reclusão pubertária. Elas devem ficar nuas, sem enfeites, quase imóveis, separadas dos demais em uma pequena casa construída especialmente para esta ocasião e são ditas "coitadas", mesmo termo usado para se referir às crianças sem enfeites.

${ }^{12}$ /Wanin/ costuma ser traduzido como "alma", "espírito", ou "mágica". Neste último caso, enfatiza-se a capacidade do xamã de tornar as coisas visíveis ou de fazê-las desaparecer.

${ }^{13}$ A referência a pinturas e enfeites corporais invisíveis aos olhos dos não xamãs aparece nas etnografias de outros povos ameríndios. Gebhard-Sayer (1986) e Colpron (2004) mencionam as pinturas corporais invisíveis dos Shipibo, e Overing (1991:21) descreve as forças de produtividade encapsuladas em "contas de vida" que, segundo os Piaroa, são trazidas pelos xamãs de suas viagens à morada dos deuses e inseridas, sob a forma de colares de contas invisíveis, nos indivíduos de sua comunidade. Essas etnografias colocam em evidência uma relação entre visibilidade/invisibilidade, interior/exterior que escapa ao modo como essas dicotomias são concebidas pelo pen- 
samento ocidental. O que parece estar em jogo nestes casos, mais do que diferentes concepções de enfeites ou de pinturas corporais, é a própria concepção do corpo, que é mais do que um suporte para os enfeites e as pinturas. Noto que, mesmo nos casos etnográficos em que não há referência a pinturas ou enfeites invisíveis, a pintura e a ornamentação corporal são muitas vezes concebidas como uma forma de tornar o corpo visível ou invisível (Erikson 1996; Lagrou 2007), indicando que, se os enfeites encobrem o corpo, o corpo também pode encobrir os enfeites.

${ }^{14}$ Esta capacidade de transformação dos xamãs está literalmente inscrita em seus corpos, seja na forma de enfeites internos, no caso dos Mamaindê, seja na forma de pinturas corporais invisíveis, no caso dos Marubo, ou ainda como as pequenas pedras que o xamã zaparo mantém dentro de uma bolsa que ele carrega consigo.

${ }^{15}$ De acordo com Guzmán-Gallegos, trata-se de "uma casa de uma família branca-mestiça que não está associada à Igreja. Essa família possui uma réplica menor da estátua do santo da igreja, assim como livros de registro nos quais os nomes daqueles afetados pelas ações maléficas de São Gonçalo estão escritos" (Guzmán-Gallegos 2009:226).

${ }^{16}$ Algo semelhante foi notado por Allard (2012:235) em relação aos Warao da Venezuela.

${ }^{17}$ É comum na Amazônia a ideia de que os espectros dos mortos desfazem o parentesco entre os vivos na medida em que desejam permanecer seus parentes, levando-os consigo. Os espectros dos mortos são, neste sentido, o oposto dos espíritos ancestrais, coletivo genérico e anônimo de espíritos dos mortos aos quais os Mamaindê se referem como "nossos avós/velhos" (nusa sunidu), mesmo termo usado para se referir aos ancestrais míticos, e a quem o xamã deve recorrer para refazer o parentesco entre os vivos nos casos de doença.

18 Taylor (1993:430) menciona algo semelhante entre os Achuar ao comentar sobre uma classe de espíritos dos mortos/espectros errantes encontrados na floresta e que desejam tornar os vivos seus parentes. Eles podem aparecer sob uma forma normal e as mulheres e as crianças podem segui-los sem se darem conta de sua verdadeira identidade. Os homens adultos sabem reconhecê-los e basta lhes dizer "eu também sou uma pessoa" e fazer um barulho para que eles desapareçam. 


\section{Referências bibliográficas}

AGOSTINHO, Pedro. 1974. Mitos e outras narrativas kamayurá. Salvador: Universidade Federal da Bahia.

ALLARD, Olivier. 2012. "Bureaucratic anxiety: asymmetrical interactions and the role of documents in the Orinoco Delta, Venezuela". Hau: Journal of Ethnographic Theory, 2(2):234-56.

BARCELOS NETO, Aristóteles. 2002. A arte dos sonhos. Uma iconografia ameríndia. Lisboa: Museu Nacional de Etnologia/ Assírio \& Alvim.

BILHAUT, Anne-Gaëlle. 2007. Le reveil de l'immateriel. La production onirique du patrimoine des indiens Zápara (Haute Amazonie). Tese de Doutorado, Université Paris $\mathrm{X}$, Nanterre.

CARNEIRODACUNHA, Maria Manuela. 1998. "Pontos de vista sobre a floresta amazônica: xamanismo e tradução". Mana. Estudos de Antropologia Social, 4(1):7-22. CESARINO, Pedro. 2008. "Babel da floresta, cidade dos brancos? Os Marubo no trânsito entre dois mundos". Novos Estudos, CEBRAP, 82:133-151.

. 2012. "A escrita e os corpos desenhados: transformações do conhecimento xamanistico entre os Marubo". Revista de Antropologia, 55:75.

COLPRON, Anne-Marie. 2004. Dychotomies sexuelles dans l'étude du chamanisme: le contre-exemple des femmes "chamanes" shipibo-conibo (Amazonie Péruvienne). Tese de Doutorado, Universidade de Montreal, Canadá.

CONKLIN, Beth. 1997. "Body paint, feathers, and vcrs: aesthetics and authenticity in Amazonian activism". American Ethnologist, 24(4):711-737.

ERIKSON, Philippe. 1996. La griffe des aïeux: marquage du corps et démarquage ethniques chez les Matis d'Amazonie. Paris: Peters.
FAUSTO, Carlos. 1999. "Of enemies and pets: warfare and shamanism in Amazonia". American Ethnologist, 26:933-956. . 2007. "Feasting on people: eating animals and eating humans in Amazonia". Current Anthropology, 48:497-530.

FIORINI, Marcelo. 1997. Embodied names: construing Nambiquara personhood through naming practices. Dissertação de Mestrado, New York University.

GALLOIS, Dominique. 1992. "Arte iconográfica waiãpi". In: Lux Vidal (org.), Grafismo indígena: estudos de antropologia estética. São Paulo: Fapesp/ Edusp.

GEBHART-SAYER. 1986. "Una terapia estética: los diseños visionarios del ayahuasca entre los Shipibo-Conibo". America Indígena, XLVI:189-218.

GELL, Alfred. 1998. Art and agency. An anthropological theory. Oxford: Oxford University Press.

GORDILLO, Gastón. 2006. "The crucible of citizenship: ID-paper fetishism in the Argentinean Chaco". American Ethnologist, 33(2):162-176.

GOW, Peter. 1990. "Could Sangama read? The origin of writing among the Piro of eastern Peru". History and Anthropology, 5:87-103.

- 1991. Of mixed blood: kinship and history in Peruvian Amazonia. Oxford: University of Oxford Press.

GUSS, David. 1990. To wave and sing: art, symbol and narrative in the South American Rain Forest. Berkeley: University of California Press.

GUZMÁN-GALlEGOS, Maria A. 2009. "Identity cards, abducted footprints, and the book of San Gonzalo: the power of textual objects in Runa worldview". In: Santos-Granero (ed.), The occult life of things. Native Amazonian 
theories of materiality and personhood. Tucson: The University of Arizona Press. pp. 214-234.

HUGH-JONES, Stephen. 1979. The palm and the pleiades: initiation and cosmology in Northwest Amazonia. Cambridge: Cambridge University Press. .2002. "Nomes secretos e riqueza visível: nominação no Noroeste Amazônico". Mana. Estudos de Antropologia Social, 8(2):45-68.

LAGROU, Els. 2007. A fluidez da forma: arte, alteridade e agência em uma sociedade amazônica (Kaxinawa, Acre). Rio de Janeiro: Topbooks.

MILLER, Joana. 2005. As coisas. Os enfeites corporais e a noção de pessoa entre os Mamaindê (Nambiquara). Tese de Doutorado, PPGAS/MN/UFRJ.

- 2009. "Things as persons: body ornaments and alterity among the Mamaindê (Nambikwara)". In: F. Santos-Granero (ed.), The occult life of things. Native Amazonian theories of materiality and personhood. Tucson: The University of Arizona Press. pp. 60-80.

OVERING, Joanna. 1991. "A estética da produção: o censo de comunidade entre os Cubeo e os Piaroa". Revista de Antropologia, 34:7-33.

PISSOLATO, Elisabeth. 2007. A duração da pessoa. Mobilidade, parentesco e xamanismo mbya (guarani). São Paulo: Editora Unesp/ISA; Rio de Janeiro: NuTI.

SAHLINS, Marshall. 2013. What kinship is - and is not. Chicago: University of Chicago Press.

SEEGER, Anthony. 1980. "O significado dos ornamentos corporais: o exemplo suyá". In: Os índios e nós. Estudos sobre sociedades tribais brasileiras. Rio de Janeiro: Editora Campus. pp. 43-57. SEEGER, Anthony; DAMATTA, Roberto \& VIVEIROS DE CASTRO, Eduardo. 1979. "A construção da pessoa nas sociedades indígenas brasileiras". Boletim do Museu Nacional, 32:1-20.
SZTUTMAN, Renato. 2012. O profeta e o principal: a ação política ameríndia e seus personagens. São Paulo: Editora da Universidade de São Paulo/ Fapesp. TAYLOR, Anne-Christine. 1993. "Des fantômes stupefiants. Language et croyance dans la pensée achuar". L'Homme, 33(126-128): 429-447.

TAYLOR, Anne-Christine \& VIVEIROS DE CASTRO, Eduardo. 2006. "Un corps fait de regards: Amazonie". In: Stephane Breton (org.), Qu'est-ce qu'un corps? Paris: Musée du Quai Branly/Flammarion. pp. 148-199.

TUGNY, R. 2008. "Um fio para o Înmõxã: em torno de uma estética maxakali". Nada, 11:52-71.

TURNER, Terence. 1992. "Os Mebengokre Kayapó: história e mudança social, de comunidades autônomas para a coexistência interétnica". In: Manuela Carneiro da Cunha (org.), História dos índios no Brasil. São Paulo: Companhia das Letras. pp. 311-338.

VAN VELTHEM, Lúcia. 2003. O belo é a fera. A estética da produção e da predação entre os Wayana. Lisboa: Assirio \& Alvim.

VIDAL, Lux. 1992. "A pintura corporal e a arte gráfica entre os Kayapó-Xikrin do Cateté". In: __ (org.), Grafismo indígena: estudos de antropologia estética. São Paulo: Studio Nobel/ Editora da Universidade de São Paulo/ Fapesp. pp. 143-189.

VILAÇA, Aparecida. 1999. "Devenir autre: chamanisme et contact interethnique en Amazonie brésilienne". Journal de la Societé des Américanistes, 885: 239-260. . 2002. "Making kin out of others". Journal of the Royal Anthropological Institute, 8(2):347-365. . 2005. "Chronically unstable bodies. Reflections on Amazonian corporalities". Journal of the Royal Anthropological Institute, 11:445-464. 
VIVEIROS DE CASTRO, Eduardo. 2002. "Perspectivismo e multinaturalismo na América indígena". In: A inconstância da alma selvagem. São Paulo: Cosac \& Naify. pp. 345-399.

_ 2004. "Exchanging perspectives: the transformation of objects into subjects in Amerindian ontologies". Common Knowledge, 10(3):463-484. . 2004. "Perspectival anthropology and the method of controlled equivocation". Tipití: Journal of the Society for the Anthropology of Lowland South America, 2(1):3-22.

- 2006. "A floresta de cristal. Notas sobre a ontologia dos espíritos amazônicos". Cadernos de Campo, 14/15:319-338. - 2009. Métaphisiques canibales. Paris: Puf. - 2011. "O medo dos outros". Revista de Antropologia, 54(2):885-917. 


\section{Resumo}

O artigo explora a comparação feita por um jovem mamaindê (um grupo Nambiquara situado no noroeste do estado do Mato Grosso) entre os seus enfeites corporais e a carteira de identidade. A importância atribuída a tais objetos, neste caso, remete aos perigos relacionados à possibilidade de perdê-los em situações específicas. Quando se trata dos enfeites corporais, enfatizam-se os riscos e as consequências de tê-los roubados pelos espíritos da floresta. Quando se trata da carteira de identidade, enfatiza-se o perigo envolvido nas relações estabelecidas com a polícia. A comparação feita pelo jovem mamaindê não foi, portanto, apenas entre os seus enfeites corporais e a carteira de identidade, mas também entre os espíritos da floresta e a polícia. Meu objetivo é refletir sobre essas duas comparações contidas na explicação do meu informante, a partir da descrição etnográfica dos Mamaindê. Pretendo demonstrar que esta comparação indica que a carteira de identidade é vista como um enfeite corporal, tal como os Mamaindê o concebem, e não o contrário. Deste modo, argumento que para este grupo Nambiquara a carteira de identidade remete, sobretudo, às noções de alteridade e de transformação, mais do que à ideia de identidade ou de representação.

Palavras-chave Carteira de identidade, Documentos, Enfeites corporais, Nambiquara/ Mamaindê, Pessoa.
Abstract

This article investigates the comparison made by a young mamaindê man (a Nambikwara group from northwestern Mato Grosso) between his body ornaments and the identity card. The importance that the Mamaindê attribute to these objects is linked to the dangers that stem from the possibility of losing them in certain situations. Where body ornaments are concerned, it is the consequences of having them stolen by the spirits of the forest that is emphasised. Where the identity card is concerned, it is the danger of relating to the police that is emphasized. The comparison is thus drawn not only between body ornaments and identity cards, but also between the spirits of the forest and the police. My aim is to consider these two comparisons established by my informant in light of Mamaindê ethnography. I will demonstrate that these comparisons indicate that the identity card is like a body ornament, as the latter are conceived by the Mamaindê, rather than the other way around. I argue that, for this Nambikwara group, the identity card is related to notions of alterity and transformation and not identity and representation.

Key words Body ornaments, Documents, Identity card, Nanbikwara/Mamainde, Person. 